\title{
Bioaccumulation of heavy metals in soil and selected food crops cultivated in Kogi State, north central Nigeria
}

\author{
J. E. Emurotu* and P. C. Onianwa
}

\begin{abstract}
Background: Heavy metal contamination in Nigeria soils is well documented. However, there is dearth of information on the intake of toxic heavy metals by some food crops cultivated in Nigeria soil. Accumulation of toxic heavy metals in edible food crops is a potential threat to human and animal health. Hence, a study on soil to food crop relation in terms of heavy metals accumulation is expedient. In this study, the levels of $\mathrm{Cd}, \mathrm{Co}, \mathrm{Cu}, \mathrm{Ni}, \mathrm{Pb}$ and $\mathrm{Zn}$ in soils and food crop samples from nine major commercial and individual farms were investigated for their contamination in soil and accumulation in food crops.

Methods: Soil samples were collected from thirty-two farmlands at two depths of 0-15 and 15-30 cm in each farm and control site, to make 320 composite samples. A total of 640 edible food crop samples (pumpkin 64, passion fruit 96, maize grain 96, sugar cane stem 64 and tubers of cassava 320) were collected.

Results: The results revealed that the levels of Cd ranged from 0.07 to $9.80 \mathrm{mg} / \mathrm{kg}$, Co $0.05-38.1 \mathrm{mg} / \mathrm{kg}$, Cu $0.33-$ $16.9 \mathrm{mg} / \mathrm{kg}$, Ni 3.81-93.1 mg/kg, Pb 4.45-47.7 mg/kg and Zn 5.02-81.4 mg/kg in topsoils. There was no significant difference $(P>0.05)$ in the levels of these heavy metals in subsoils and among farms. Except in pumpkin, nickel concentration in all the investigated food crops exceeded regulatory limits set by the World Health Organization and the Food and Agriculture Organization. Similarly, the concentration of $\mathrm{Cd}$ and $\mathrm{Co}$ in pumpkin exceeded regulatory limits. Soil-plant transfer factors indicated low accumulation into crops except Co in maize and Ni in cassava.

Conclusion: Therefore, soil may require mild remediation action to minimize possible sources of Co and Ni contamination such as irrigation and fertilizer application practices. The concentration of $\mathrm{Cd}$ in food crops could be of health concern if such crops are ingested.
\end{abstract}

Keywords: Heavy metals, Soil contamination, Farmlands, Food crops, Metal uptake

\section{Background}

The underlying geological composition of soils has been reported to be a major source of heavy metal contamination of soil. The level of heavy metal in soils and the forms in which they exist are influenced by pedogenetic processes (Herawati et al. 2000). Prolonged farming activities involving the use of fertilizers, herbicides and insecticides also contribute to soil pollution. Rapid industrialization has also brought about dangerous pollution of soil by heavy metals in many countries (Makino et al.

\footnotetext{
*Correspondence: judrotu@yahoo.com
}

Department of Chemistry, University of Ibadan, Ibadan, Nigeria
2010). The pollution of soils with heavy metal is of global concern as a result of its potential impact on the environment and to human health. Vast portions of farmlands have been contaminated by metals as result of the activities of mining, smelting, fossil fuel burning, phosphate fertilizers and sewage sludge (Navarro et al. 2008). Based on high toxicity of heavy metals, their accumulation in farmland could lead to contamination of agricultural soil. Once soil is contaminated, it will not only affect the rapid growth of crops and quality yield of agricultural products but also pose a threat to human health via the food chain (Salazar et al. 2012; Zhao et al. 2014; Zhuang et al. 2009). This is of increasing concern worldwide (Sun et al. 2013). 
Soil-to-crop transfer of heavy metals is the major pathway of human exposure to heavy metals. Increase in human population has placed a demand for increased food supply. This has resulted in increased use of pesticides, fertilizers, manures, composts, and wastewater for irrigation. Food crops grown in metal-contaminated soil can uptake and accumulate metals in quantities high enough to affect food quality and safety (Muchuweti et al. 2006). Most countries have devoted serious attention to the monitoring of heavy metals in food crops resulting from contamination of agricultural soils (Herawati et al. 2000). Previous studies revealed that heavy metal concentration in soils as well as food crops were above regulatory standards (Lalor 2008). The concentration of cadmium in soils of certain regions of Jamaica has been reported to be remarkably high (Lalor et al. 1998). In their study Lalor et al. (1998) reported a wide range of Cd concentrations in non-mineralized Jamaican soils. Similarly, Salazar and Pignata (2014) reported high level of lead exceeding national and international norms in soils and native plants in Córdoba, Argentina. Uptake and transfer of heavy metals through food crops are affected by the level of metals in soils, soil properties, $\mathrm{pH}$, age of food crop, food crop types and species (Rafiq et al. 2014; $\mathrm{Xu}$ et al. 2015; Yang et al. 2015). It becomes imperative to evaluate heavy metal uptake by food crops and assess the potential health risks.

A nation such as Nigeria where agricultural activities are intensive and food production is high, it is important to monitor contaminant level in soils and food crops to determine the degrees of soil contamination and migration into food crops. Farming is a very important and major activity in Kogi State. The State is considered as one of the food basket regions of Nigeria. The National Food Reserve Agency (2008) reported that cassava production in Kogi State increased from 2.8 million metric tons to 3.6 million metric tons in 2003, which is the highest in Nigeria. The state's per hectare yield is currently 14.88 tons, which is among the highest in Nigeria. Data also indicated that Kogi State is the fourth largest producer of maize in Nigeria. The farms are owned by government parastatals, corporate private organizations, and individuals. It is therefore imperative to monitor agricultural soils and examine food crops grown thereon. In the Kogi State farmland environment, there is paucity of data on the level of metals in agricultural soils and available food crops. This research work was designed with the overall aim of assessing the levels of $\mathrm{Cd}, \mathrm{Co}$, $\mathrm{Cu}, \mathrm{Ni}, \mathrm{Pb}$, and $\mathrm{Zn}$ in farmlands and food crops grown in Kogi State farmland. The focus of this study is on food crops and the attendant food safety issues and potential health risks.

\section{Methods}

\section{Description of study area}

Kogi State in north central Nigeria as shown in Fig. 1 was selected for this study based on its huge annual food production. It lies within the savannah belt with vegetation of typical rainforest, Guinea savannah and mangrove forests. The topography is underlain by igneous and metamorphic rocks belonging to the basement complex and sedimentary rock of upper cretaceous age which is of embedded shale, sand clays, sandstone and mindstone. It enjoys the tropical continental climate characterized by rainy and dry seasons. Average rainfall annually ranges from 1200 to $1500 \mathrm{~mm}$ while temperature is high almost throughout the year except during the harmattan period. The harmattan period sets in early November and lasts until February. The nature of soils in this zone is majorly ultisol, sandy loam and loamy sand. The food crops are mainly cassava, maize, yam, sugar cane and vegetables.

\section{Soil sampling and characterization}

Soils were collected from cropping areas in nine farmlands and a control site. Samples were collected quarterly for 2 years across the three senatorial districts of Kogi State, namely Kogi Central, Kogi West and Kogi East respectively. Soils were obtained at the depth of 0-15 and $15-30 \mathrm{~cm}$ in each farm and control site, to make 320 composite samples. Samples from the surroundings of each site were homogenized to obtain an individual composite sample (Khan et al. 2008). Following a systematic sampling, ten sub subsamples were collected within an area of $10 \mathrm{~m}$ by $10 \mathrm{~m}$ with a stainless steel hand auger sampler to make a composite. The sampled locations are shown in Fig. 1. The collected samples were dried at ambient temperature, ground and sieved with a $<2 \mathrm{~mm}$ mesh and kept in polyethylene packages till analysis. Soil $\mathrm{pH}$ was measured in $\mathrm{H}_{2} \mathrm{O}$ (soil:water $=1: 1$ ) suspension electrometrically in duplicate (Bäckström et al. 2004). Soil particle size analysis was carried out as described by Gee and Bauder (1979). Organic carbon of dry soil samples was determined by the Walkley-Black method (Walkly and Black 1934). The heavy metals in soil were extracted using aqua regia and the digest were determined for $\mathrm{Cd}, \mathrm{Co}, \mathrm{Cu}, \mathrm{Ni}, \mathrm{Pb}$, and $\mathrm{Zn}$ concentration by atomic absorption spectrophotometry.

\section{Sampling and analysis of food crops}

Cassava (Manihot utilisima Crantz), maize (Zea mays L), pumpkin (Cucurbita pepo L) and passion fruits (Passiflora edulis Sims) and sugar cane (Sacchanarum officinarum) that are standing food crop samples were taken simultaneously along with the soil samples (Khan et al. 2008) based on their availability. The number of collected samples was 640 . Subsamples of leaves, fruits, grain, stem 


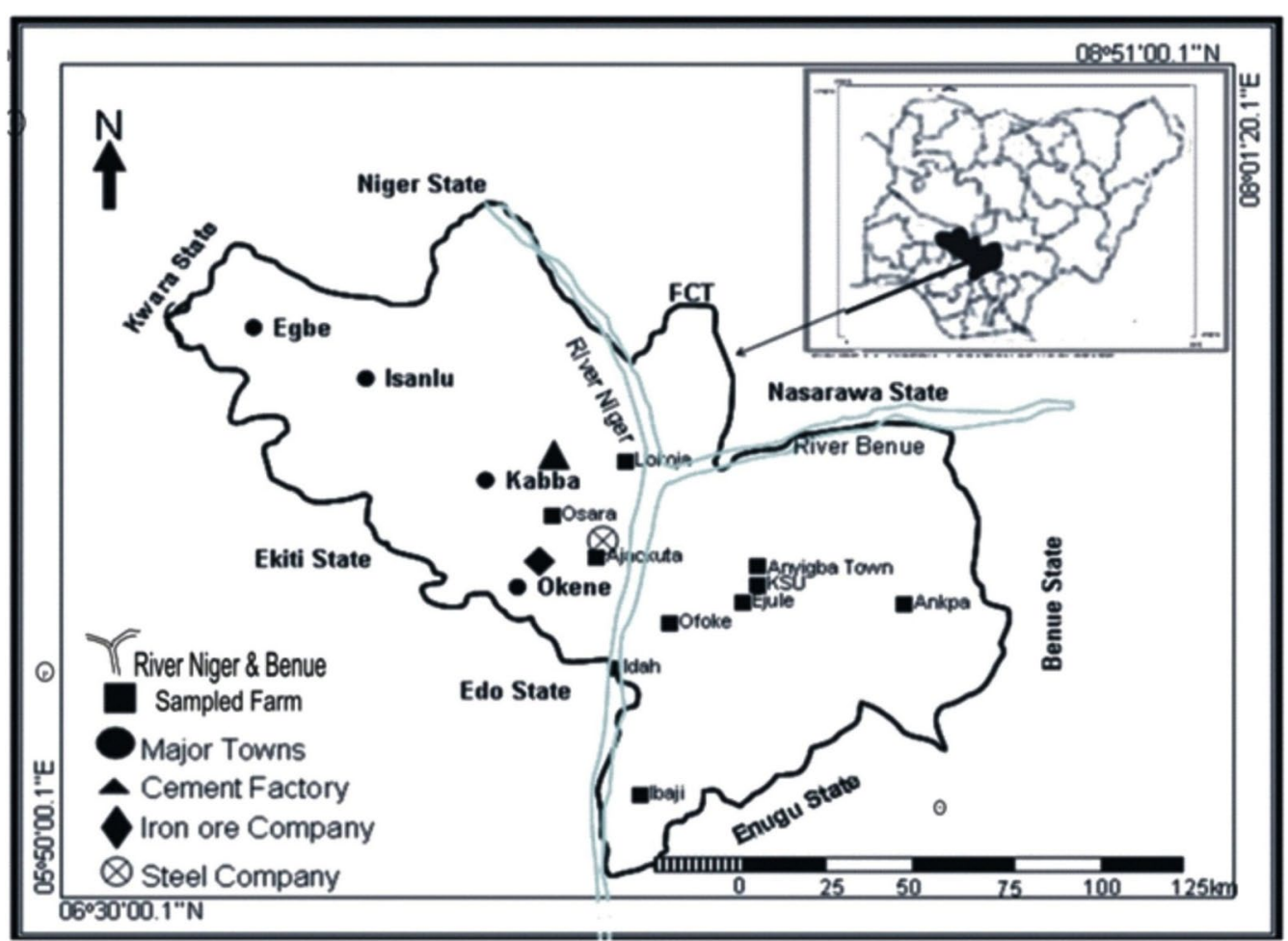

Fig. 1 Sampled farmlands location

and tuber of crops were collected each within an area of $10 \mathrm{~m}$ by $10 \mathrm{~m}$ to make a composite. Samples were divided into fruits, grains, tubers, stem and leave. Each food crop was washed with distilled water and spread out for drying. Air-dried samples were ground and sieved with a $2 \mathrm{~mm}$ mesh and stored at ambient temperature in polyethylene bags till analysis. Crop samples were extracted using a mixture of $\mathrm{HNO}_{3}: \mathrm{HClO}_{4}$ (3:1). The digest were determined for $\mathrm{Cd}, \mathrm{Co}, \mathrm{Cu}, \mathrm{Ni}, \mathrm{Pb}$, and $\mathrm{Zn}$ concentration by atomic absorption spectrophotometry.

\section{Quality assurance and statistical analysis}

Samples were generally analysed in duplicates. Each sample was ground with a porcelain mortar and pestle. All glassware used for analysis was thoroughly washed with Teepol, soaked in $2 \mathrm{M}$ nitric acid for $24 \mathrm{~h}$ and rinsed with de-ionised water. Stock standard solutions were prepared from Analar R grade salts. Dilute aliquots as working standards were made from the stock solutions. Freshly prepared reagents were standardized for actual strength. Analytical grade chemicals and reagent blanks were used in all analyses to check reagent impurities. A sample blank digestion was also prepared after every 10 samples. Recovery study for heavy metal was carried out to check the accuracy and precision of the entire experimental procedure. Average recoveries obtained were acceptable at $81 \pm 16$ to $105 \pm 18 \%$. Data obtained were subjected to analysis of variance using the general linear models. Two way analysis of variance (ANOVA) $(<0.05)$ were used to assess whether metal concentrations in soil varied significantly between rainy and dry seasons. All statistical calculations were performed with SPSS 17.0 for Windows.

\section{Analysis of data \\ Transfer factor}

The transfer factors (TF) of heavy metals from soils to crops were calculated as follows (Cui et al. 2005):

$$
\mathrm{TF}=\frac{\text { metal concentration in crop extract }}{\text { metal concentration in soil on dry weight basis }} .
$$

The soil-to-plant transfer factor, can also be called accumulation factor, uptake factor or concentration factor, is regarded as an index for evaluating the transfer potential of a metal from soil to plant (Zheng et al. 2007).

\section{Index of geoaccumulation}

The extent of each heavy metal in the soils and contamination level was measured using the index of geo-accumulation $\left(\mathrm{I}_{\text {geo }}\right)$ of metals in soils.

$$
\text { Geoaccumulation index }\left(I_{\text {geo }}\right)=\log _{2}\left[\frac{C_{n}}{1.5 \times B_{n}}\right] \text {, }
$$


(Muller 1969) where $C_{n}$ is the determined concentration of the examined metal in the soil and $B_{n}$ is the geochemical background concentration of the same metal. Factor 1.5 is the background matrix correction factor. Index of geo-accumulation $\left(\mathrm{I}_{\text {geo }}\right)$ of metals in soils as a tool will indicate the contamination status of the soils depending on the range, from uncontaminated, slightly contaminated or extremely contaminated.

\section{Results}

\section{Physicochemical properties of soils}

The physicochemical characteristics of the soils tested are given in Table 1. The results indicated that soils $\mathrm{pH}$ were weakly acidic. Topsoil $\mathrm{pH}$ ranged from 5.59 to 6.90. Lower $\mathrm{pH}$ in soils has been attributed to intensive farming practices (Song et al. 2012; Yang et al. 2015). Average topsoil and subsoil pH was $6.29 \pm 0.18$ and $5.89 \pm 0.15$ respectively. The level of total organic carbon (TOC) in topsoil was $4.87 \pm 0.47 \%$, and in subsoil, it was $4.55 \pm 0.24 \%$. TOC content in topsoil ranged from 3.82 to $10.1 \%$. The corresponding TOC values for control soils were 4.32 and $11.3 \%$. Total organic matter (TOM) varied from 6.60 to $17.5 \%$ with an average value of $7.85 \%$. Mayuri et al. (2016) have reported that some fractions of metals can be bound with organic content therefore the determination of organic carbon in soil is very important. Similarly, the TOM values in control soils were not significantly different as values ranged from 7.46 to $20.1 \%$ with an average value of $9.3 \%$. Soil organic matter can influence the uptake of heavy metals by plants. Higher organic matter has been attributed to over-fertilization especially organic fertilizers (Song et al. 2012; Yang et al. 2015). The soils' clay contents were less than $20 \%$ and such soils are classified as coarse textured soils (Komarek et al. 2008).
Generally, the soil textural characteristics ranged from loamy sand to sandy loam.

\section{Levels of heavy metals in soils}

Heavy metal content of soils from the area studied and control site are shown in Table 2. The concentrations of the metals are in the order: $\mathrm{Zn}>\mathrm{Ni}>\mathrm{Pb}>\mathrm{Co}>\mathrm{Cu}>\mathrm{Cd}$ in the soils. The maximum value for each metal followed the same order except for $\mathrm{Ni}$ which had a higher maximum value than $\mathrm{Zn}$. The results indicated that all the metal concentrations are within Canadian regulated limits and European Union regulated limits for agricultural soils as shown in Table 2. However, there is gradual build up of $\mathrm{Ni} \mathrm{Pb}$ and $\mathrm{Zn}$ compared to the control site. Geoaccumulation index $\left(\mathrm{I}_{\text {geo }}\right)$ rating indicated that all topsoil $(0-15 \mathrm{~cm})$ analysed belong to unpolluted class $(<0)$ except lead and $\mathrm{Zn}$ with Igeo value of 0.48 and 0.63 respectively that fall within the category of class 1 of slightly polluted. The $I_{\text {geo }}$ rating for cadmium was $<0$ for all samples. This indicated that soil samples were uncontaminated with respect to cadmium level. Therefore cadmium level in soils is not from anthropogenic activity rather it could be from parent material that formed the soil.

\section{Heavy metals accumulation in food crops}

The levels of metals in edible parts of food crops are reported in Fig. 2 The order of magnitude of heavy metal concentrations was $\mathrm{Zn}>\mathrm{Ni}>\mathrm{Cu}>\mathrm{Pb}>\mathrm{Cd}>\mathrm{Co}$ for maize and sugar cane. The order was the same for passion fruit and cassava except that $\mathrm{Ni}$ had a higher value than $\mathrm{Zn}$. Pumpkin had a pattern of $\mathrm{Zn}>\mathrm{Cu}>\mathrm{Ni}>\mathrm{Co}>\mathrm{Cd}>\mathrm{Pb}$. The acceptable permissible limits of $\mathrm{Cd}(0.1-0.2)$, Co (0.01), Cu (20), Ni (10),

Table 1 Physicochemical properties of farmland

\begin{tabular}{|c|c|c|c|c|c|c|c|c|}
\hline \multirow[t]{2}{*}{ Properties } & \multirow[t]{2}{*}{ Depth $(\mathrm{cm})$} & \multicolumn{4}{|c|}{ Farmland soils $(n=300)$} & \multicolumn{3}{|c|}{ Control soils $(n=32)$} \\
\hline & & Range & Mean & SD & Median & Range & Mean & SD \\
\hline \multirow[t]{2}{*}{$\mathrm{pH}$} & $0-15$ & $5.59-6.90$ & 6.29 & 0.27 & 6.73 & $5.08-7.20$ & 6.87 & 0.76 \\
\hline & $15-30$ & $5.20-6.49$ & 5.88 & 0.37 & 633 & $5.70-7.24$ & 6.18 & 0.66 \\
\hline \multirow[t]{2}{*}{ OC (\%) } & $0-15$ & $3.82-10.1$ & 4.87 & 0.18 & 4.55 & $4.32-11.3$ & 5.6 & 2.3 \\
\hline & $15-30$ & $3.39-6.74$ & 4.55 & 0.12 & 4.34 & $3.73-6.01$ & 4.44 & 0.08 \\
\hline \multirow[t]{2}{*}{ OM (\%) } & $0-15$ & $6.60-17.5$ & 8.45 & 0.47 & 7.85 & $7.46-20.1$ & 9.3 & 4.6 \\
\hline & $15-30$ & $5.58-11.7$ & 7.87 & 0.24 & 7.50 & $6.50-10.4$ & 7.33 & 0.33 \\
\hline \multirow[t]{2}{*}{ Sand (\%) } & $0-15$ & $47.0-84.4$ & 72 & 15 & 78.3 & $75.5-84.4$ & 76.7 & 4.6 \\
\hline & $15-30$ & $44.5-82.4$ & 71 & 13 & 75.5 & $66.7-79.6$ & 75.0 & 5.9 \\
\hline \multirow[t]{2}{*}{ Silt (\%) } & $0-15$ & $4.60-36$ & 12.4 & 8.5 & 9.3 & $4.20-6.80$ & 7.0 & 1.9 \\
\hline & $15-30$ & $4.60-34.1$ & 12.2 & 9.6 & 9.50 & $4.20-8.60$ & 8.5 & 4.8 \\
\hline \multirow[t]{2}{*}{ Clay (\%) } & $0-15$ & $10.8-21.5$ & 15.6 & 6.9 & 15.8 & $10.6-17.9$ & 14.3 & 3.9 \\
\hline & $15-30$ & $10.6-22.0$ & 16.6 & 6.3 & 17.3 & $16.2-24.7$ & 17.5 & 6.1 \\
\hline
\end{tabular}


Table 2 Total soil heavy metals content of farmland

\begin{tabular}{|c|c|c|c|c|c|c|c|c|c|c|}
\hline \multirow[t]{2}{*}{ Properties } & \multirow[t]{2}{*}{ Depth (cm) } & \multicolumn{4}{|c|}{ Farmland soils $(n=300)$} & \multicolumn{3}{|c|}{ Control soils $(n=32)$} & \multicolumn{2}{|c|}{ Regulated limits (mg/kg) } \\
\hline & & Range & Mean & SD & Median & Range & Mean & SD & CCME (1999) & EU (2002) \\
\hline \multirow[t]{2}{*}{$\mathrm{Cd}$} & $0-15$ & $0.07-9.80$ & 0.60 & 0.7 & 0.14 & $0.03-1.92$ & 0.64 & 0.79 & 1.4 & 3.0 \\
\hline & $15-30$ & $0.03-9.43$ & 0.37 & 0.07 & 0.20 & $0.02-2.11$ & 0.72 & 0.87 & & \\
\hline \multirow[t]{2}{*}{ Co } & $0-15$ & $0.05-38.1$ & 6.0 & 7.1 & 4.31 & $1.09-3.83$ & 2.6 & 1.1 & 40 & - \\
\hline & $15-30$ & $0.16-36.4$ & 4.9 & 3.2 & 3.09 & $0.02-5.68$ & 2.5 & 1.8 & & \\
\hline \multirow[t]{2}{*}{$\mathrm{Cu}$} & $0-15$ & $0.33-16.9$ & 4.8 & 3.9 & 4.38 & $1.08-8.17$ & 2.7 & 2.4 & 63 & 140 \\
\hline & $15-30$ & $0.32-12.9$ & 1.5 & 2.4 & 3.13 & $0.32-7.72$ & 2.5 & 2.4 & & \\
\hline \multirow[t]{2}{*}{$\mathrm{Ni}$} & $0-15$ & $3.81-93.1$ & 17 & 14 & 13.7 & $4.43-18.5$ & 9.6 & 5.2 & 50 & 75 \\
\hline & $15-30$ & $3.28-68.4$ & 12.8 & 1.5 & 11.9 & $3.20-12.6$ & 8.3 & 3.9 & & \\
\hline \multirow[t]{2}{*}{$\mathrm{Pb}$} & $0-15$ & $4.45-47.7$ & 12.8 & 8.2 & 12.1 & $3.79-13.7$ & 6.1 & 3.2 & 70 & 300 \\
\hline & $15-30$ & $3.21-30.3$ & 11.7 & 2.2 & 12.1 & $2.31-19.0$ & 5.7 & 5.5 & & \\
\hline \multirow[t]{2}{*}{$\mathrm{Zn}$} & $0-15$ & $5.02-81.4$ & 28 & 23 & 17.9 & $7.46-28.5$ & 11.6 & 6.9 & 200 & 300 \\
\hline & $15-30$ & $4.67-84.4$ & 25.0 & 8.5 & 16.2 & $6.12-20.2$ & 9.8 & 4.6 & & \\
\hline
\end{tabular}

$\mathrm{Pb}$ (9) and $\mathrm{Zn}$ (100) $\mathrm{mg} / \mathrm{kg}$ for food were stipulated by SEPA (2005) and FAO/WHO (2011) as regulatory bodies. Average concentration of determined metals $(\mathrm{Pb}, \mathrm{Cu}, \mathrm{Zn}$ and $\mathrm{Cd}$ ) in food crops did not exceed permissible limits except the mean concentration of $\mathrm{Cd}(0.41 \pm 0.42 \mathrm{mg} / \mathrm{kg})$ in pumpkin (Table 3 ). The mean concentration of cobalt in pumpkin $(0.47 \pm 0.82 \mathrm{mg} / \mathrm{kg})$, maize $(0.12 \pm 0.13 \mathrm{mg} /$ $\mathrm{kg})$ and cassava $(0.20 \pm 0.05 \mathrm{mg} / \mathrm{kg})$ exceeded the permissible limit. Also, the observed concentration of $\mathrm{Ni}$ in passion fruit, cassava and sugar cane exceeded the permissible limit. The concentrations of nickel were significantly higher $(\mathrm{P}<0.05)$ in cassava tuber and maize grain samples. The Ni level in cassava varied from 5.32 to $47.3 \mathrm{mg} / \mathrm{kg}$ and in maize grain concentration ranged from 2.9 to $46.2 \mathrm{mg} / \mathrm{kg}$. Though average Cd concentrations in food crops were within standard limit, the values suggest a gradual increase. Table 3 shows that maximum $\mathrm{Cd}$ accumulation was in pumpkin $(0.12-2.17 \mathrm{mg} / \mathrm{kg})$ while the minimum accumulation was in sugar cane (0.11$0.27 \mathrm{mg} / \mathrm{kg}$ ). Maize, passion fruit, and cassava had similar range of accumulation. The level of $\mathrm{Pb}$ in food crops varied from 0.03 to $0.75 \mathrm{mg} / \mathrm{kg}$. Similarly, concentration

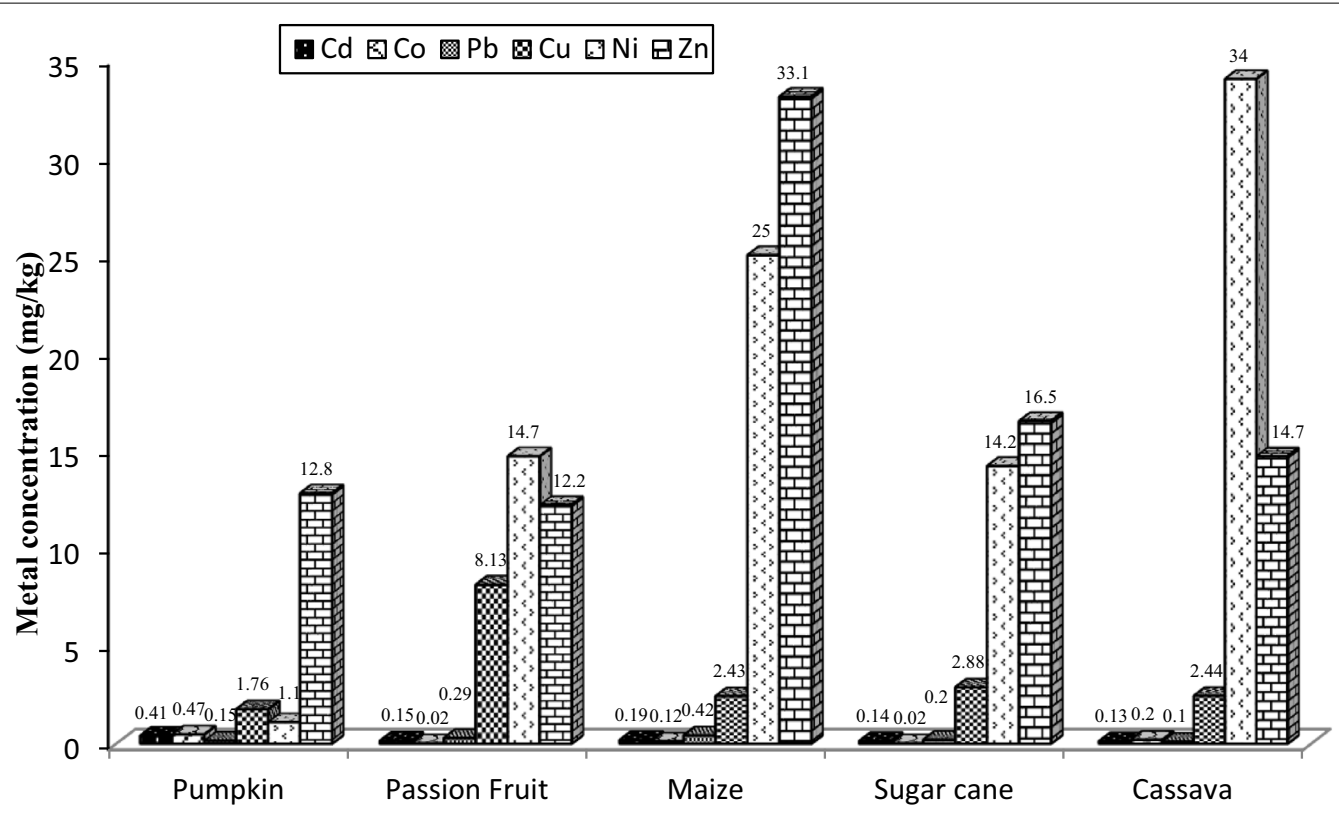

Fig. 2 Average concentrations $(\mathrm{mg} / \mathrm{kg}$ ) of metals in edible part of crops 
Table 3 Heavy metal content ( $\mathrm{mg} / \mathrm{kg}$ ) of food crop of farmland

\begin{tabular}{llllllll}
\hline Crops & Values & Cd & Co & $\mathbf{C u}$ & $\mathbf{N i}$ & $\mathbf{P b}$ & $\mathbf{Z n}$ \\
\hline Pumpkin & Range & $0.12-2.17$ & $0.01-3.17$ & $1.36-2.60$ & $0.06-5.54$ & $0.07-0.27$ & $1.81-20.9$ \\
& Mean + SD & $0.41 \pm 0.42$ & $0.47 \pm 0.82$ & $1.76 \pm 0.19$ & $1.1 \pm 1.2$ & $0.15 \pm 0.05$ & $12.8 \pm 6.1$ \\
Maize & Range & $0.15-0.30$ & $0.02-0.55$ & $1.61-2.88$ & $2.9-46.2$ & $0.16-0.75$ & $30.6-40.4$ \\
& Mean + SD & $0.19 \pm 0.03$ & $0.12 \pm 0.13$ & $2.43 \pm 0.29$ & $25 \pm 10$ & $0.42 \pm 0.22$ & $33.1 \pm 2.4$ \\
Passion fruit & Range & $0.09-0.28$ & $0.01-0.02$ & $7.23-9.80$ & $8.04-30.6$ & $0.04-0.13$ & $6.63-19.7$ \\
& Mean + SD & $0.15 \pm 0.05$ & $0.02 \pm 0.01$ & $8.13 \pm 0.29$ & $14.7 \pm 6.2$ & $0.29 \pm 0.17$ & $12.2 \pm 3.1$ \\
Cassava & Range & $0.01-0.29$ & $0.01-0.05$ & $0.60-4.61$ & $5.32-47.3$ & $0.03-0.31$ & $3.08-29.3$ \\
& Mean + SD & $0.13 \pm 0.01$ & $0.20 \pm 0.05$ & $2.44 \pm 0.17$ & $34 \pm 19$ & $0.10 \pm 0.01$ & $14.7 \pm 1.7$ \\
Sugar cane & Range & $0.11-0.27$ & $0.01-0.03$ & $2.41-3.65$ & $10.5-20.4$ & $0.04-0.32$ & $11.9-19.0$ \\
& Mean + SD & $0.14 \pm 0.04$ & $0.02 \pm 0.01$ & $2.88 \pm 0.23$ & $14.2 \pm 2.3$ & $0.20 \pm 0.12$ & $16.5 \pm 0.8$ \\
Standard limit & & $0.1-0.2^{\mathrm{ab}}$ & $0.01^{\mathrm{a}}$ & $20^{\mathrm{ab}}$ & $10^{\mathrm{b}}$ & $9^{\mathrm{b}}, 0.3^{\mathrm{ac}}$ & $100^{\mathrm{ab}}$ \\
\hline
\end{tabular}

a FAO/WHO (2011)

b SEPA (2005)

c EEC (1977)

of $\mathrm{Cu}$ varied from 0.60 to $9.80 \mathrm{mg} / \mathrm{kg}$, while $\mathrm{Zn}$ varied between 1.81 and $40.4 \mathrm{mg} / \mathrm{kg}$. The levels of metals in food crops samples were generally of the order maize $>$ cassava $>$ passion fruit $>$ sugar cane $>$ pumpkin. The difference observed regarding heavy metals accumulations in different food crops determined reflected different rate of food crops in absorbing heavy metals (Pandey and Pandey 2009) and mobility of the metals.

\section{Transfer of metals from soils into food crops}

The transfer factors (TF) of metals into crops are shown in Table 4. Average transfer factor observed for considered metals were $\mathrm{Cd}(0.21-1.68)$, Co (0.07-2.48), $\mathrm{Cu}$ (0.38-1.01), Ni (0.11-2.21), $\mathrm{Pb}(0.01-0.03)$ and $\mathrm{Zn}$ (0.51-1.96). The sequence of TF for these metals in different food crops is $\mathrm{Co}>\mathrm{Ni}>\mathrm{Zn}>\mathrm{Cd}>\mathrm{Cu}>\mathrm{Pb}$. This is an indication that Co was the most bio-available. The correlations of $\mathrm{TF}$ for $\mathrm{Cd}$ with $\mathrm{pH}$ and $\mathrm{TOC}$ resulted to a regression of -0.707 and -0.089 respectively. Organic carbon content and $\mathrm{pH}$ are soil parameters having influence on TF.

$\mathrm{Xu}$ et al. (2013) have reported the net influence of organic matter in decreasing or increasing metal mobility. There is significant correlation between TF of $\mathrm{Cd}$ and clay content. General, positive correlations were observed among soil $\mathrm{Ni}, \mathrm{Cd}, \mathrm{Co}$ and $\mathrm{Cu}$. Significantly, negative correlation was established between $\mathrm{Pb}$ and $\mathrm{pH}$, whereas with organic carbon it was positive. Ying et al. (2014) also reported similar correlation result. TOC showed positive correlation with $\mathrm{Ni}, \mathrm{Cd}$ and $\mathrm{Cu}$ and negative correlation with $\mathrm{Pb}$ and $\mathrm{Co}$. Such relationship has been reported to indicate binding nature of metal ions to organic substances and its absorption to soil particles (Mayuri et al. 2016).

\section{Discussion}

Average values of total organic matter (TOM) in topsoil and subsoil were functions of the organic carbon. The differences observed between sample values and control value were not significant $(\mathrm{P}>0.05)$. This shows that there is no local difference in soil texture and general characteristics of these soils. The soil particle size (\%) variations intra farms and with depth were not significant $(\mathrm{P}>0.05)$ (Table 2). Soil type ranged from sandy loam to loamy sand. The TOM values are adequate for agricultural farmland. Organic matter increases buffering and exchange capacity of soils and makes nutrient available to crops (McCauley et al. 2009). It also form chelates with metals such as $\mathrm{Cu}$ and $\mathrm{Zn}$ which increase their solubility and make their availability to crops. However, an increase

Table 4 Transfer factor of metals into crops

\begin{tabular}{lllllll}
\hline Food crops & $\mathbf{C u}$ & $\mathbf{Z n}$ & $\mathbf{P b}$ & $\mathbf{C d}$ & $\mathbf{N i}$ & $\mathbf{C o}$ \\
\hline Maize $(\mathrm{n}=10)$ & 0.71 & 1.96 & 0.03 & 1.68 & 0.77 & 2.48 \\
Passion fruit $(\mathrm{n}=10)$ & 0.77 & 0.51 & 0.01 & 0.21 & 0.44 & 0.69 \\
Pumpkin $(\mathrm{n}=10)$ & 0.38 & 0.57 & 0.01 & 0.88 & 0.11 & 0.07 \\
Cassava $(\mathrm{n}=20)$ & 1.01 & 0.54 & 0.03 & 1.10 & 2.21 & 1.06 \\
\hline
\end{tabular}


in organic carbon or organic matter leads to a stronger adsorption to soil particles by metals. This decreases their mobility and availability to crops. A low availability of heavy metals can also be expected as $\mathrm{pH}$ of the soil play a significant role in the solubility of metals in soil solution (Mico et al. 2006). Once the availability of metals in soil solution is low the uptake by metals will as well be low. This probably accounted for low level experienced in farmland soils. However, Kabata-Pendias and Pendias (1992) have reported that increase in soil $\mathrm{pH}$ in some cases does not lead to decrease in heavy metal availability. For instance, a high $\mathrm{Cd}$ accumulation and toxicity in a high pH soil has been reported (Eriksson 1989).

In this study area, all metals determined were within CCME and SEPA permissible limits in farmland soils. The concentration of $\mathrm{Pb}$ in this research is similar to values reported by Iyaka and Kakulu (2012) for agricultural soils in Minna, Niger State but different from those reported for agricultural soils of Enyigba, Ebonyi State (Nweke et al. 2008) and Yargalma area of Zamfara State, Nigeria (Tsafe et al. 2012). Unlike other metals, the concentration of $\mathrm{Cd}$ is higher in subsoil in most of the farms. However, the differences between topsoil and subsoil levels were insignificant $(P>0.05)$. Higher level of cadmium observed in subsoil is supported by values obtained for the soil texture. At some of the farms were the concentration of $\mathrm{Cd}$ is highest at subsoil, \% silt is highest at the subsoil and also the \% sand is lowest at the subsoil. These factors will support higher capacity to retain pollutants. The range of cadmium concentration in this study is significantly different $(P<0.05)$ from the range of values obtained from a similar study in Kano (Abdu et al. 2011) and in southwest Nigeria (Olatunji et al. 2013). The average nickel concentration decreases from topsoil to subsoil but inter and intra farm differences were not significant $(\mathrm{P}>0.05)$. Nickel, copper and zinc have been reported to be highly mobile in acidic mediums. This mobility is made possible because these metals form sulphides which are sparingly soluble (Mattigod and Page 1983). Since the concentration of metals in the farmland did not exceed the permitted levels allowed in agricultural use, the food crops obtained presently may not have a toxicological risk for direct consumption by humans (Blanco et al. 2016).

The mean concentration of $\mathrm{Cd}$ and $\mathrm{Co}$ in pumpkin indicates contamination as levels were above $\mathrm{FAO} / \mathrm{WHO}$ and SEPA permissible limits. This indicates that pumpkin might cause a potential risk of $\mathrm{Cd}$ for human and animal consumption. The presence of $\mathrm{Cd}$ in food crops is dangerous due to its toxicity effect. This effect arises from the fact that cadmium can react with some enzymes in the body and alter their catalytic activity (Alloway and Ayres 1997). Also, previous studies have revealed relatively higher $\mathrm{Cd}$ accumulated in food crops like spinach and $\mathrm{Pb}$ in tomato (Hu et al. 2013; Huang et al. 2014). Cd is seen as potential carcinogens and has been attributed to the cause of a number of diseases, such as cardiovascular, blood, kidney, and nervous system as well as bone diseases (Jarup 2003; WHO/FAO 2007). Except in pumpkin, the concentration of $\mathrm{Ni}$ in maize, cassava, sugar cane and passion fruits was above FAO/WHO and SEPA permissible limits. Too much dietary intake of farm produce contaminated with $\mathrm{Cd}$ and Ni can lead to serious health challenge (Oliver 1997). The concentrations of $\mathrm{Pb}, \mathrm{Cu}$ and $\mathrm{Zn}$ in food crops in this research were within permissible limits.

Across all soils, positive correlations observed between soil $\mathrm{Cd}$ and organic carbon were not significant $(r=0.069)$, but highly significant with soil $\mathrm{Ni}(r=0.95)$ as shown in Table 5 .

Similarly, positive linear correlations observed between soil $\mathrm{Cu}$ and organic carbon was not significant $(\mathrm{r}=0$. 043). This probably accounted for the low Cu levels in topsoil.

Human exposure to heavy metals via food chain has been well documented by researchers. Soil-to-plant

Table 5 Correlation coefficient among metals and properties of soil

\begin{tabular}{|c|c|c|c|c|c|c|c|c|c|}
\hline & $\mathrm{pH}$ & TOC & том & $\mathrm{Cu}$ & $\mathrm{Zn}$ & $\mathrm{Pb}$ & $\mathrm{Cd}$ & $\mathrm{Ni}$ & Co \\
\hline $\mathrm{pH}$ & 1 & & & & & & & & \\
\hline TOC & -0.096 & 1 & & & & & & & \\
\hline TOM & -0.095 & $1.000^{b}$ & 1 & & & & & & \\
\hline $\mathrm{Cu}$ & -0.113 & 0.043 & 0.043 & 1 & & & & & \\
\hline $\mathrm{Zn}$ & -0.107 & 0.029 & 0.030 & $0.519^{b}$ & 1 & & & & \\
\hline $\mathrm{Pb}$ & 0.164 & -0.171 & -0.171 & $0.300^{b}$ & 0.168 & 1 & & & \\
\hline $\mathrm{Cd}$ & -0.053 & 0.069 & 0.070 & $0.409^{b}$ & $0.238^{a}$ & 0.061 & 1 & & \\
\hline $\mathrm{Ni}$ & -0.107 & 0.142 & 0.143 & $0.514^{b}$ & $0.486^{b}$ & 0.193 & 0.95 & 1 & \\
\hline Co & 0.167 & -0.029 & -0.028 & $0.752^{b}$ & $0.390^{b}$ & $0.346^{b}$ & $0.364^{b}$ & $0.644^{b}$ & 1 \\
\hline
\end{tabular}

\footnotetext{
a Correlation is significant at the 0.05 level (2-tailed)
}

${ }^{\mathrm{b}}$ Correlation is significant at the 0.01 level (2-tailed) 
transfer is a key factor always used to assess this exposure risk. Soil-plant uptake factors revealed that accumulation of heavy metals into crops investigated were low, except for nickel in cassava and Co in maize with moderate enrichment.

\section{Conclusions}

This study revealed that the levels of heavy metals in soils from Kogi farmlands were low and fell within the regulatory standards requirements for metals in farmland setting. Although the metals level in agricultural soils did not exceed regulatory permissible limits, however, the observed concentration of $\mathrm{Ni}$ in food crops except pumpkin exceeded regulatory standards and could pose potential health risk to the consumer. The concentrations of $\mathrm{Cd}$ and Co in pumpkin exceeded regulatory limits, however, it should not be of concern presently as this crop did not present a toxicological risk for direct consumption by humans as values were little folds higher than the safe limits. Soil-plant uptake factors revealed that accumulation of heavy metals into the crops investigated was low, except for nickel in cassava and Co in maize. The concentrations of metals in food crops do not pose a major health concern at present. Further study should include vegetables and other food crops. A detailed speciation study is recommended at different soil layers to establish the forms in which the heavy metals are present in the soil, considering their hazardous effects.

\section{Authors' contributions \\ JEE design and carried out the research work. He collected the samples and did the laboratory work. The write up and statistical analysis was done by me under the supervision of the co-author. PCO the research project was conducted under the supervision of PCO the co-author. He did not only read the work but also meaningful corrections and suggestions. Both authors read and approved the final manuscript.}

\section{Competing interests}

The authors declare that they have no competing interests.

\section{Availability of data and materials}

General data repository and workflow management/versioning connects to other services; free-Open Science Framework.

\section{Consent for publication}

Not applicable.

Ethics approval and consent to participate

Not applicable.

\section{Funding}

Not applicable.

\section{Publisher's Note}

Springer Nature remains neutral with regard to jurisdictional claims in published maps and institutional affiliations.

Received: 22 December 2016 Accepted: 27 August 2017

Published online: 06 September 2017

\section{References}

Abdu N, Abdulkadir Aagbenin JO, Buerkert A (2011) Vertical distribution of heavy metals in wastewater-irrigated vegetable garden soils of three West African cities. Nutr Cycl Agroecosyst 89:387-397

Alloway BJ, Ayres DC (1997) Chemical principals for environmental pollution. Blackie Academic and Professional, London, pp 190-220

Bäckström M, Karlsson S, Allard B (2004) Metal leachability and anthropogenic signal in roadside soils estimated from sequential extraction and stable lead isotopes. Environ Monit Assess 90:135-160

Blanco A, Salazar MJ, Cid CV, Pereyra C, Lilia R, Cavaglieri LR, Becerra AG, Pignata ML, Judith H, Rodriguez JH (2016) Multidisciplinary study of chemical and biological factors related to $\mathrm{Pb}$ accumulation in sorghum crops grown in contaminated soils and their toxicological implications. J Geochem Explor 166:18-26

CCME (Canadian Council of Ministers of the Environment) (1999) Canadian soil quality guidelines for the protection of environmental and human health: summary tables. In: Canadian environmental quality guidelines, Canadian Council of Ministers of the Environment, Winnipeg

Cui Y, Zhu YG, Zhai R, Huang V, Qiu Y, Liang J (2005) Exposure to metal mixtures and human health impacts in a contaminated area in Nanning, China. Environ Int 31:784-790

EEC (European Communities) (1977). Council directive of 29 March on biological screening of the population for lead. 77/312/EEC. Official Journal of the European Communities L1 05/-17, 28 April

Eriksson JE (1989) The influence of pH, soil type and time on adsorption and uptake of cadmium. Water Air Soil Pollut 48:317

EU (European Union) (2002) Heavy metals in wastes, European Commission on Environment. http://ec.europa.eu/environment/waste/studies/pdf/ heavymetalsreport.pdf. Accessed 06 Oct 2012

FAO/WHO (2011) Joint FAO/WHO food standards programme codex committee on contaminants in foods fifth session. The Hague, The Netherlands, March 2011

Gee GW, Bauder V (1979) Particle size analysis by hydrometer: a simplified method for routine textural analysis and a sensitivity test of measurement parameters. Soil Sci Soc Am J 43:1004-1007

Herawati N, Suzuki S, Hayashi K, Rivai IF, Koyama H (2000) Cadmium, Copper, and zinc levels in rice and soil of Japan, Indonesia, and China by soil type. Bull Environ Contam Toxicol 64:33-39

Hu WY, Huang B, Shi XZ, Chen WP, Zhao YC, Jiao WT (2013) Accumulation and health risk of heavy metals in a plot-scale vegetable production system in a pen-urban vegetable farm near Nanjing, China. Ecotoxicol Environ Saf 98:303-309

Huang Z, Pan XD, Wu PG, Han JL, Chen Q (2014) Heavy metals in vegetables and the health risk to population in Zhejiang, China. Food Control 36:248-252

lyaka YA, Kakulu SE (2012) Heavy metal concentrations in top agricultural soils around ceramic and pharmaceutical industrial sites in Niger State, Nigeria. Res J Environ Earth Sci 4(2):171-176

Jarup L (2003) Hazards of heavy metal contamination. Brit Med Bull 68:167-182

Kabata-Pendias A, Pendias H (1992) Trace elements in soils and plants, 2nd edn. CRC Press, Boca Raton, p 365

Khan S, Cao Q, Zheng YM (2008) Health risk of heavy metals in contaminated soils and food crops irrigated with waste water in Beijing, China. Environ Pollut 152:686-692

Komarek M, Szakova J, Rohoskova M, Javorska H, Chrastny V, Balík J (2008) Copper contamination of vineyard soils from small wine producers: a case study from the Czech Republic. Geoderma 14(1-2):16-22

Lalor CG (2008) Review of cadmium transfers from soil to humans and its health effects in the Jamaican environment. Sci Total Environ 400(1-3):162-172

Lalor GC, Raitray R, Simpson P, Vutchkov M (1998) Heavy metals in Jamaica. Part 3: the distribution of cadmium in Jamaican soils. Rev Int Contam Ambient 14(1):7-12

Makino T, Luo Y, Wu L, Sakurai Y, Maejima Y, Akahane I, Arao T (2010) Heavy metal pollution of soil and risk alleviation methods based on soil chemistry. Pedologist 53(3):38-49

Mattigod SV, Page AL (1983) Assessment of metal pollution in soils. In: Thornton I (ed) Applied environmental geochemistry. Academic Press, Cambridge, pp 355-394 
Mayuri C, Amit M, Arvind KN, Sanjay KG, Rajendra KK (2016) Heavy metal contamination in vegetables grown around periurban and urban-industrial clusters in Ghaziabad, India. Hum Ecol Risk Assess 22(3):736-752

McCauley A, Jone C, Jacobsen J (2009) Soil pH and organic matter. In: Nutrient management module no 8. http://landresources.montana.edu/nm/ documents/NM8.pdf. Accessed 10 Aug 2015

Mico C, Peris M, Sanchez J, Recatala L (2006) Heavy metal content of agricultural soils in a Mediterranean semiarid area: the Segura River Valley (Alicante, Spain). Span J Agric Res 4(4):363-372

Muchuweti M, Birkett JW, Chinyanga E (2006) Heavy metal content of vegetables irrigated with mixtures of wastewater and sewage sludge in Zimbabwe: implication for human health. Agric Ecosyst Environ 112:41-48

Muller G (1969) Index of geoaccumulation in sediments of the Rhine River. GeoJournal 2:108-118

Navarro M, Pérez-Sirvent C, Martínez-Sánchez M, Vidal J, Tovar P, Bech J (2008) Abandoned mine sites as a source of contamination by heavy metals: a case study in a semi-arid zone. J Geochem Explor 96:183-193

NFRA (National Food Reserve Agency) (2008). Report of 2007Agricultural Production Survey (APS), Federal Ministry of Agriculture and Water Resources, October 2008

Nweke FN, Okaka ANC, Offor EC (2008) Lead, zinc and pH concentrations of Enyigba soils in Abakaliki local government area of Ebonyi State, Nigeria. Afr J Biotechnol 7(14):2441-2443

Olatunji SO, Opeolu BO, Fatoki O, Ximba BJ (2013) Heavy metals concentration levels in selected arable agricultural soils in South Western Nigeria. Int J Phys Sci 8(11):421-427

Oliver MA (1997) Soil and human health: a review. Eur J Soil Sci 48:573-592

Pandey J, Pandey U (2009) Accumulation of heavy metals in dietary vegetables and cultivated soil horizon in organic farming system in relation to atmospheric deposition in a seasonally dry tropical region of India. Environ Monit Assess 148:61-74

Rafiq MT, Aziz R, Yang XE, Xiao WD, Stoffella PJ, Saghir A, Azam M, Li TQ (2014) Phytoavailability of cadmium (Cd) to Pak Choi (Brassica chinensis L.) grown in chinese soils: a model to evaluate the impact of soil $\mathrm{Cd}$ pollution on potential dietary toxicity. PLoS ONE 9(11):111461

Salazar MJ, Pignata ML (2014) Lead accumulation in plants grown in polluted soils. Screening of native species for phytoremediation. J Geochem Explor 137:29-36

Salazar MJ, Rodriguez JH, Nieto GL, Pignata ML (2012) Effects of heavy metal concentrations ( $\mathrm{Cd}, \mathrm{Zn}$ and $\mathrm{Pb}$ ) in agricultural soils near different emission sources on quality, accumulation and food safety in soybean [Glycine max (L.) Merrill]. J Hazard Mater 233-234:244-253
SEPA (State Environmental Protection Administration) of China (2005) Environmental Yearbook. China Environmental Sciences Press, Beijing

Song H, Guo JH, Ren T, Chen Q, Li BG, Wang JG (2012) Increase of soil pH in a solar greenhouse vegetable production system. Soil Sci Soc Am J 76:2074-2082

Sun FF, Wang FH, Wang X, He W, Wen DA, Wang QF, Liu XX (2013) Soil threshold values of total and available cadmium for vegetable growing based on field data in Guangdong province, South China. J Sci Food Agric 93:1967-1973

Tsafe Al, Hassan LG, Sahabi DM, Alhassan Y, Bala BM (2012) Evaluation of Heavy Metals Uptake and Risk Assessment of Vegetables Grown in Yargalma of Northern Nigeria. J Basic Appl Sci Res 2(7):6708-6714

Walkly A, Black IA (1934) An examination of the Degtjareff method for determining soil organic matter and proposed modification of the chromic acid titration method. Soil Sci 37:29-38

WHO/FAO (World Health Organization/Food and Agriculture Organization) (2007) Joint FAO/WHO food standard programme codex alimentarius commission 13th session. Report of the thirty eight session of the codex committee on food hygiene, Houston, USA; ALINORM 07/30/13

Xu DC, Zhou P, Zhan J, Gao Y, Dou CM, Sun QY (2013) Assessment of trace metal bioavailability in garden soils and health risks via consumption of vegetables in the vicinity of Tongling mining area, China. Ecotoxicol Environ Saf 90:103-111

Xu L, Lu AX, Wang JH, Ma ZH, Pan LG, Feng XY, Luan YX (2015) Accumulation status, sources and phytoavailability of metals in greenhouse vegetable production systems in Beijing, China. Ecotoxicol Environ Saf 122:214-220

Yang LQ, Huang B, Mao MC, Yao LP, Hickethier M, Hu WY (2015) Trace metal accumulation in soil and their phytoavailability as affected by greenhouse types in north China. Environ Sci Pollut Res 22:6679-6686

Ying C, Pingping W, Yufang S, Yibin Y (2014) Health risk assessment of heavy metals. Sci Agric 71(2):126-132

Zhao Y, Fang X, Mu Y, Cheng Y, Ma Q, Nian H, Yang C (2014) Metal pollution (Cd, $\mathrm{Pb}, \mathrm{Zn}$, and $\mathrm{As}$ ) in agricultural soils and soybean, Glycine max, in southern China. Bull Environ Contam Toxicol 92:427-432

Zheng N, Wang Q, Zhang X, Zheng D, Zhang Z, Zhang S (2007) Population health risk due to dietary intake of heavy metals in the industrial area of Huludao city, China. Sci Total Environ 387:96-104

Zhuang P, McBride MB, Xia H, Li N, Li Z (2009) Health risk from heavy metals via consumption of food crops in the vicinity of Dabaoshan mine, South China. Sci Total Environ 407:1551-1561

\section{Submit your manuscript to a SpringerOpen ${ }^{\circ}$ journal and benefit from:}

- Convenient online submission

- Rigorous peer review

- Open access: articles freely available online

- High visibility within the field

Retaining the copyright to your article

Submit your next manuscript at springeropen.com 